\title{
Changed plant and animal life cycles from 1952 to 2000 in the Mediterranean region
}

\author{
JOSEP PEÑUELAS*, IOLANDA FILELLA* and PERE. COMAS† \\ *Unitat Ecofisiologia CSIC-CREAF, CREAF (Center for Ecological Research and Forestry Applications), Edifici C, Universitat \\ Autònoma de Barcelona, 08193 Bellaterra (Barcelona), Spain, †Cardedeu Field Station, C/Sant Miquel, 7, 08440 Cardedeu, \\ Barcelona, Spain
}

\begin{abstract}
The available data on climate over the past century indicate that the earth is warming. Important biological effects, including changes of plant and animal life cycle events, have already been reported. However, evidence of such effects is still scarce and has been mostly limited to northern latitudes. Here we provide the first long-term (1952-2000) evidence of altered life cycles for some of the most abundant Mediterranean plants and birds, and one butterfly species. Average annual temperatures in the study area (Cardedeu, NE Spain) have increased by $1.4{ }^{\circ} \mathrm{C}$ over the observation period while precipitation remained unchanged. A conservative linear treatment of the data shows that leaves unfold on average 16 days earlier, leaves fall on average 13 days later, and plants flower on average 6 days earlier than in 1952. Fruiting occurs on average 9 days earlier than in 1974. Butterflies appear 11 days earlier, but spring migratory birds arrive 15 days later than in 1952. The stronger changes both in temperature and in phenophases timing occurred in the last 25 years. There are no significant relationships among changes in phenophases and the average date for each phenophase and species. There are not either significant differences among species with different Raunkiaer life-forms or different origin (native, exotic or agricultural). However, there is a wide range of phenological alterations among the different species, which may alter their competitive ability, and thus, their ecology and conservation, and the structure and functioning of ecosystems. Moreover, the lengthening of plant growing season in this and other northern hemisphere regions may contribute to a global increase in biospheric activity.
\end{abstract}

Keywords: bird migration, butterfly appearance, climate change, flowering, fruiting, leaf fall, leaf unfolding, phenology

Received 13 July 2001; revised version received and accepted 6 November 2001

\section{Introduction}

The life cycles of most organisms are strongly influenced by temperature and precipitation. Current and future warmer conditions (IPCC, 2001) are likely to alter those seasonal plant and animal activities that respond to degree days (accumulated temperature), such as flowering or fruiting in plants or animal migratory patterns. These possible interannual variations in phenology should constitute sensitive observable indicators of biospheric changes in response to current warming (IPCC, 2001). But these possible changes are, moreover, of critical ecological

Correspondence: Josep Peñuelas, fax +34 93 5811312,

e-mail: josep.penuelas@uab.es. importance as they may affect ecosystem structure and functioning via species competitive ability and/or net primary productivity. Recent data sets and reports indicating changes in phenological stages in plants, insects, birds and amphibians (Crick et al., 1997; Scharwtz, 1998; Walkowszky, 1998; Bradley et al., 1999; Menzel \& Fabian, 1999; Hughes, 2000; Abu-Asab et al., 2001; Peñuelas \& Filella, 2001) provide evidence that ecosystems are responding to climate change. However, evidence of such effects is still scarce because it has been mostly limited to temperate and cold ecosystems of northern latitudes and to a few species. In this study we summarize data from 1952 to 2000 forming complete phenological information about some of the most abundant plant and migratory bird species, and one common butterfly. The data were 
collected at Cardedeu field station $\left(41^{\circ} 34^{\prime} \mathrm{N}, 2^{\circ} 21^{\prime} \mathrm{E}\right)$ (35 Km north of Barcelona, Catalonia, NE Spain), i.e. in a Mediterranean country, under warmer and drier climate conditions and lower latitudes than in most previous studies. These data show significant biological effects of climate warming outside of the most northern latitudes where air temperature increase has been the largest.

\section{Materials and methods}

From 1952 to 2000, the dates of the following phenological phases: leaf unfolding, flowering, fruiting, and leaf fall (and therefore leaf life) were recorded for 103 plant species by one of us (P. C) in the area surrounding Cardedeu field station in a long-term monitoring programme of meteorology and phenology for that area. The resulting data set is currently one of the longest homogeneous records in the world (Burroughs, 1992). The arrivals (first sighting or listening) of 6 migratory bird species, and the first appearance of one butterfly species were also followed yearly. Most of the monitored species are very common and abundant in Catalonia and are representative for the entire Mediterranean region. Monitoring was conducted by daily sighting and listening from key points, plus surveys of 5-10 km circuit within the $100 \mathrm{~km}^{2}$ study site. This study site is located in a plain with small topographic variability, and includes forests, agricultural fields and gardens. Phenological events were recorded with an estimated accuracy of \pm 1 day after monitoring several individuals (more than 5). They were recorded always by the same person (P.C) when the whole plant individuals had reached the functional phenological stage.

For all available phenological records covering more than 20 years (25 deciduous woody species for leaf unfolding, 26 deciduous woody species for leaf fall, 24 deciduous woody species for leaf life, 57 plant species for flowering, 27 plant species for fruiting, 6 bird species for first sighting or first listening and 1 butterfly species for first sighting) we calculated linear annual trends and their significance according to $F$-test. The number of advanced or delayed days for each phenophase and species was calculated from linear regressions with time, as the difference between the timing of leaf unfolding at the study onset and the timing at the end of the study. We also used the number of days of departure from average phenophase date per species to calculate linear annual trends in a standardized way for all species together. These data were also analysed by several statistical techniques, including principal components analysis and multiple regression using the SPSS-X, SYSTAT and STATVIEW packages. Stepwise multiple regressions were performed to determine the effect of temperature and precipitation in previous months to the phenophase

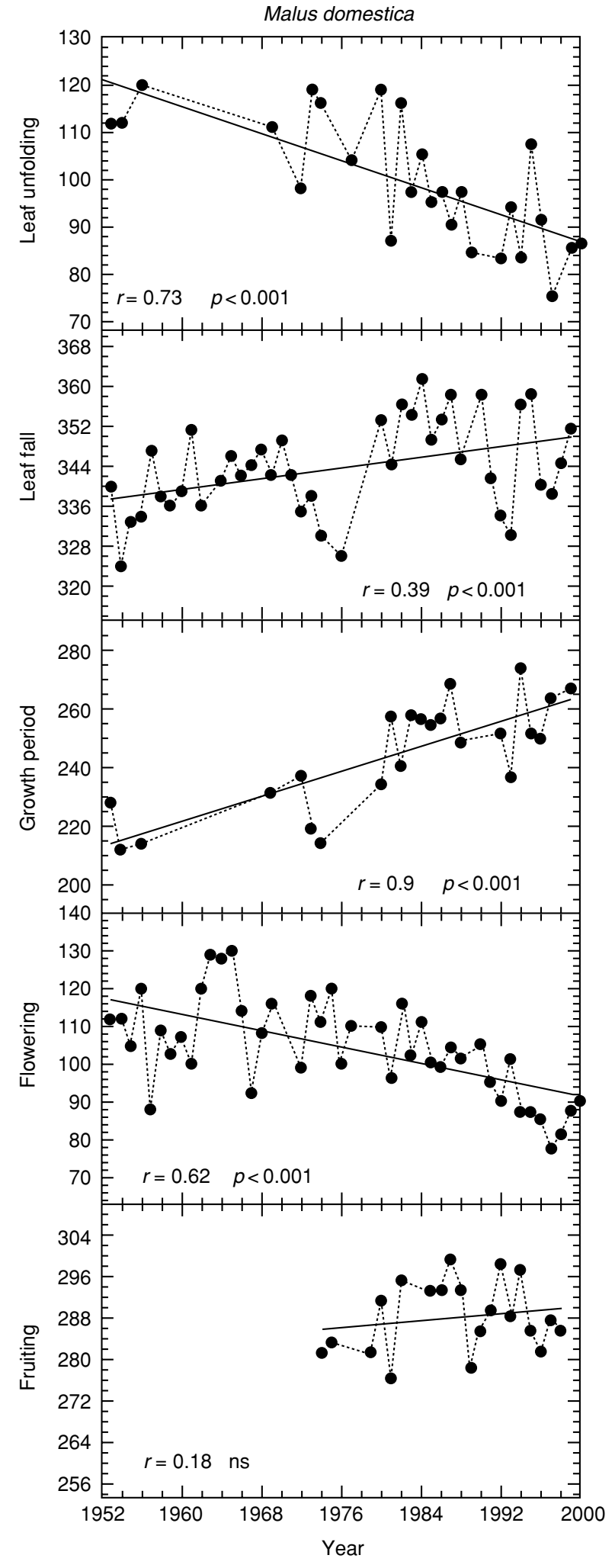

Fig. 1 Phenological changes in Malus domestica as example species growing in Cardedeu field station (NE Spain) from 1952 to 2000. Lines represent linear regressions that were fitted to the data. 


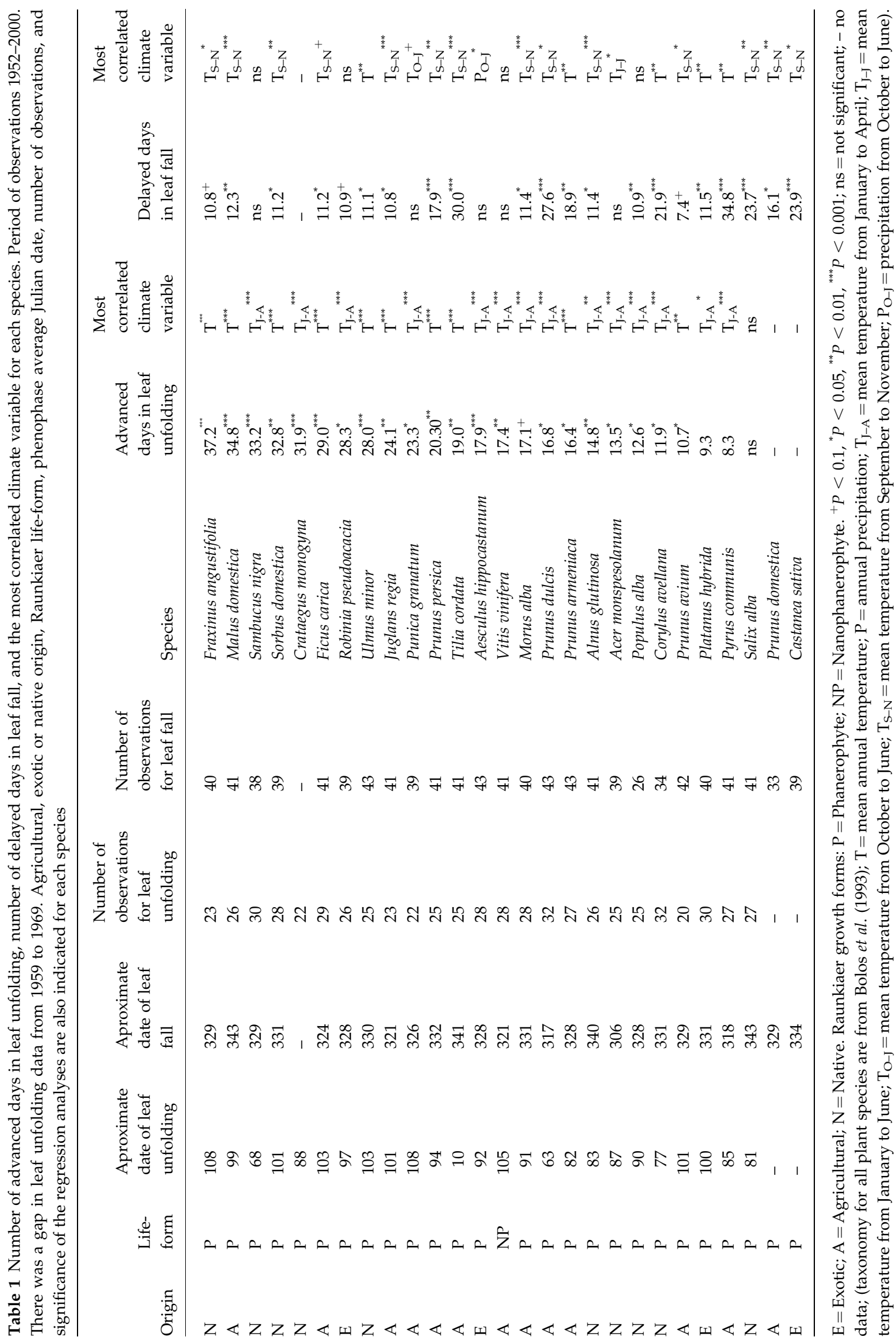

(C) 2002 Blackwell Science Ltd, Global Change Biology, 8, 531-544 
date. Inter-annual variability of leafing, flowering and fruiting was also analysed in the different decades. Regression analyses were also performed between the changes in phenophases and the average Julian date for each phenophase and species. Finally, ANovas were conducted with the changes in phenophase timing as dependent variables and the different Raunkiaer life-forms and the different origin (agricultural, native or exotic) of the studied species as independent variables.

\section{Results and discussion}

\section{Plant responses}

Species linear trends of leaf unfolding, leaf fall, flowering and fruiting throughout the study period Figure 1 shows an example of the phenological trends for one of the monitored species, apple trees, Malus domestica, for which data are available for all the studied phenological traits. During the period 1952-2000, its leaf unfolding has been advanced 35 days, its leaf fall has been delayed 12 days, its leaf life has been extended 47 days, and its flowering has been advanced 26 days, and during the period 1974-2000 its fruiting date has not significantly changed. When considering the whole data set, regression analyses showed that leaf unfolding has been significantly advanced in 24 species, and has not significantly changed in the other one (Table 1, Fig. 2a). The advance in these 48 years has ranged between 8 and 37 days depending on the species, and the overall species average advance has been 20.3 (SEM, standard error of the mean, 1.9) days (calculated considering 0 days for the species with statistically nonsignificant trend). The regression analyses also showed that leaf fall have been delayed in 21 of the 26 studied species, and has not significantly changed in the other 5 species. (Table 1, Fig. 2b). The delay has ranged between 7 and 35 days depending on the species, and the overall species average delay has been 13.3 (SEM 1.87) days. As a consequence, the leaf life and growing season have been extended in the 24 monitored species. (Table 1, Fig. 2c). The extended period has ranged between 14 and 49 days depending on the species, and the overall species (a)

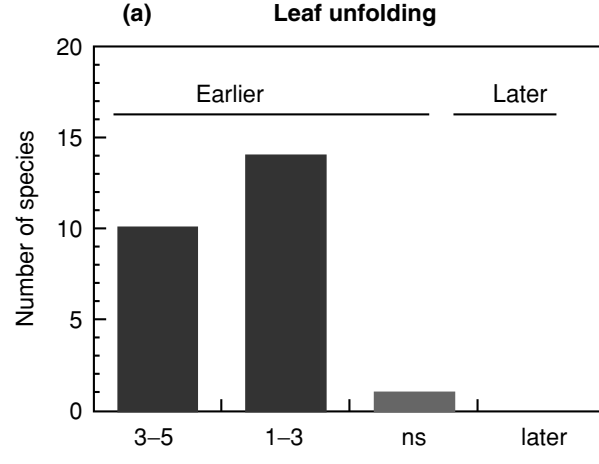

(b)

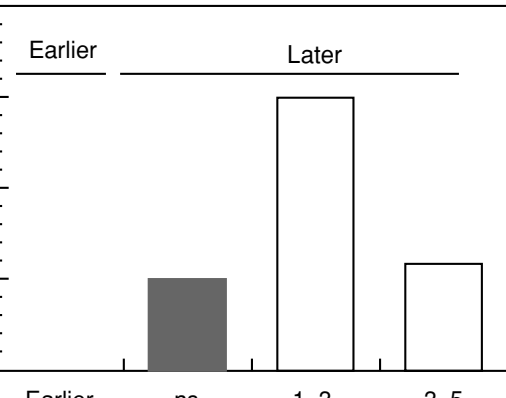

Weeks (c)

Growth period

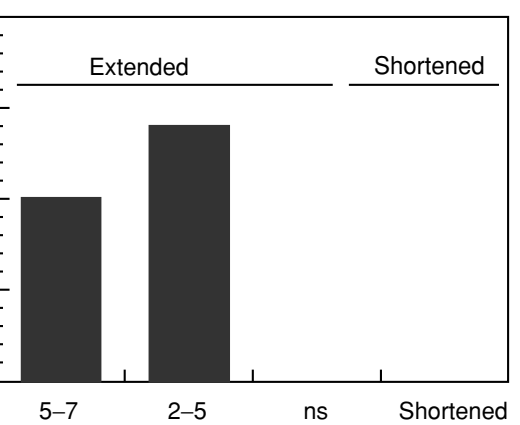

(d)

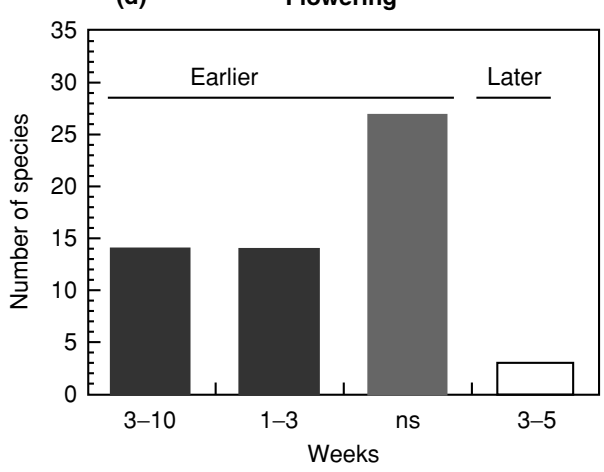

(e)

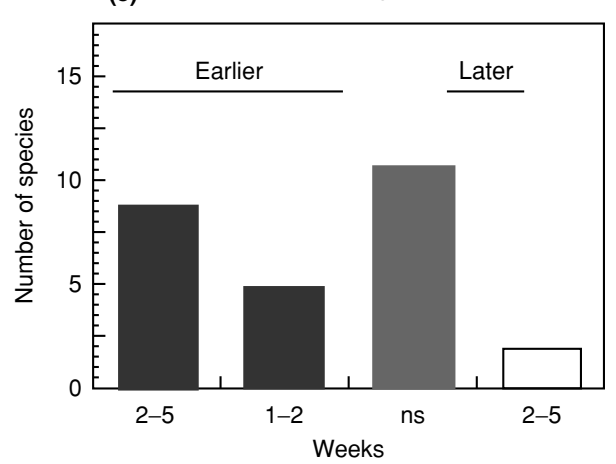

Fig. 2 Phenological changes in plant species of Cardedeu field station (NE Spain) from 1952 to 2000 . Frequency distribution of the species with advancing and delaying trends in phenophases. (a) Leaf unfolding dates for 25 species, (b) leaf fall dates for 26 species, (c) leaf life for 24 species, (d) flowering date for 57 species, and (e) fruiting date for 27 species. Significant trends $(P<0.05)$ are shown in black for advances or white for delays; nonsignificant in grey. 
Table 2 Number of advanced days of flowering and the most correlated climate variable for each species. Period of observations 1952-2000. Agricultural, exotic or native origin, Raunkiaer life-form, average Julian date of flowering, number of observations, and significance of the regression analyses are also indicated for each species

\begin{tabular}{|c|c|c|c|c|c|c|}
\hline Origin & $\begin{array}{l}\text { Life- } \\
\text { forms }\end{array}$ & $\begin{array}{l}\text { Aproximate } \\
\text { date of } \\
\text { flowering }\end{array}$ & $\begin{array}{l}\text { Number of } \\
\text { observations }\end{array}$ & Species & $\begin{array}{l}\text { Advanced } \\
\text { days in } \\
\text { Flowering }\end{array}$ & $\begin{array}{l}\text { Most } \\
\text { correlated } \\
\text { climatic factor }\end{array}$ \\
\hline A & $\mathrm{P}$ & 195 & 22 & Lippia triphylla & $70.1^{* * *}$ & $\mathrm{~T}_{\mathrm{J}-\mathrm{J}}^{* * *}$ \\
\hline $\mathrm{N}$ & $\mathrm{P}$ & 51 & 35 & Alnus glutinosa & $54^{* * *}$ & $\mathrm{~T}_{\mathrm{J}-\mathrm{A}} * *$ \\
\hline $\mathrm{N}$ & $\mathrm{P}$ & 146 & 20 & Rubus ulmifolius & $42.7^{* * *}$ & $\mathrm{~T}^{* * *}$ \\
\hline $\mathrm{N}$ & $\mathrm{P}$ & 123 & 21 & Spartium junceum & $31.9^{* *}$ & $\mathrm{~T}_{\mathrm{J}-\mathrm{J}}^{* *}$ \\
\hline A & $\mathrm{T}$ & 191 & 25 & Helianthus annuus & $30.0^{*}$ & $\mathrm{~T}^{* *}$ \\
\hline A & $\mathrm{P}$ & 104 & 43 & Malus domestica & $26.5^{* * *}$ & $\mathrm{~T}^{* * *}$ \\
\hline $\mathrm{A}$ & $\mathrm{T}$ & 98 & 31 & Pisum sativum & $25.5^{*}$ & $\mathrm{~T}_{\mathrm{J}-\mathrm{A}}^{* * *}$ \\
\hline $\mathrm{E}$ & $\mathrm{P}$ & 47 & 25 & Acacia farnesiana & $24.1^{*}$ & $\mathrm{~T}_{\mathrm{J}-\mathrm{A}}^{* *}$ \\
\hline $\mathrm{N}$ & C & 224 & 25 & Asparagus acutifolius & $22.8^{+}$ & $\mathrm{T}_{\mathrm{O}-\mathrm{F}}^{* *}$ \\
\hline $\mathrm{A}$ & $\mathrm{H}$ & 112 & 27 & Onobrychis vicifolia & $22.8^{+}$ & ns \\
\hline $\mathrm{N}$ & $\mathrm{P}$ & 83 & 27 & Laurus nobilis & $21.6^{* * *}$ & $\mathrm{~T}_{\mathrm{J}-\mathrm{A}}^{* * *}$ \\
\hline $\mathrm{N}$ & $\mathrm{P}$ & 77 & 40 & Ulmus minor & $21.5^{* *}$ & $\mathrm{~T}_{\mathrm{J}-\mathrm{A}}{ }^{* * *}$ \\
\hline $\mathrm{E}$ & $\mathrm{P}$ & 162 & 37 & Castanea sativa & $21.0^{*}$ & $\mathrm{~T}_{\mathrm{J}-\mathrm{J}}^{* * *}$ \\
\hline A & $\mathrm{T}$ & 83 & 33 & Vicia faba & $20.1^{* *}$ & $\mathrm{~T}_{\mathrm{J}-\mathrm{A}}^{* * *}$ \\
\hline $\mathrm{N}$ & $\mathrm{P}$ & 72 & 40 & Crataegus monogyna & $18.6^{* *}$ & $\mathrm{~T}_{\mathrm{J}-\mathrm{A}}^{* * *}$ \\
\hline $\mathrm{N}$ & $\mathrm{T}$ & 104 & 30 & Papaver roheas & $17.7^{+}$ & $\mathrm{T}_{\mathrm{J}-\mathrm{A}}^{* * *}$ \\
\hline $\mathrm{N}$ & $\mathrm{P}$ & 134 & 21 & Ulex parviflorus & $16.0^{* *}$ & $\mathrm{~T}_{\mathrm{J}-\mathrm{A}}^{*}$ \\
\hline A & $\mathrm{P}$ & 61 & 43 & Prunus domestica & $15.5^{* *}$ & $\mathrm{~T}_{\mathrm{J}-\mathrm{A}}^{* * *}$ \\
\hline A & $\mathrm{P}$ & 38 & 41 & Prunus dulcis & $15.5^{*}$ & $\mathrm{~T}_{\mathrm{J}-\mathrm{A}}{ }^{* * *}$ \\
\hline $\mathrm{E}$ & $\mathrm{P}$ & 123 & 39 & Robinia pseudoacacia & $14.1^{*}$ & $\mathrm{~T}_{\mathrm{J}-\mathrm{J}}^{* * *}$ \\
\hline $\mathrm{A}$ & $\mathrm{P}$ & 87 & 44 & Prunus avium & $14.0^{* *}$ & $\mathrm{~T}_{\mathrm{J}-\mathrm{A}}^{* * *}$ \\
\hline $\mathrm{A}$ & $\mathrm{P}$ & 68 & 40 & Prunus armeniaca & $13.0^{*}$ & $\mathrm{~T}_{\mathrm{J}-\mathrm{A}}^{* * *}$ \\
\hline $\mathrm{A}$ & $\mathrm{T}$ & 151 & 42 & Cicer arietinum & $12.4^{* *}$ & $\mathrm{~T}_{\mathrm{O}-\mathrm{F}}{ }^{* * *}$ \\
\hline $\mathrm{A}$ & $\mathrm{P}$ & 96 & 41 & Cydonia oblonga & $11.1^{*}$ & $\mathrm{~T}_{\mathrm{J}-\mathrm{A}}^{* * *}$ \\
\hline $\mathrm{N}$ & $\mathrm{P}$ & 34 & 37 & Corylus avellana & $10.8^{+}$ & $\mathrm{T}_{\mathrm{J}-\mathrm{A}}^{* * *}$ \\
\hline $\mathrm{N}$ & $\mathrm{P}$ & 130 & 42 & Quercus ilex & $7.8^{+}$ & $\mathrm{T}_{\mathrm{J}-\mathrm{J}}^{* *}$ \\
\hline A & $\mathrm{P}$ & 77 & 43 & Prunus persica & $6.7^{+}$ & $\mathrm{T}_{\mathrm{J}-\mathrm{A}}^{* * *}$ \\
\hline $\mathrm{A}$ & NP & 157 & 45 & Vitis vinifera & ns & $\mathrm{T}_{\mathrm{J}-\mathrm{J}}^{* *}$ \\
\hline $\mathrm{N}$ & $\mathrm{P}$ & 155 & 44 & Olea europea & ns & $\mathrm{T}_{\mathrm{J}-\mathrm{J}}^{*}$ \\
\hline $\mathrm{N}$ & $\mathrm{P}$ & 29 & 21 & Salix cinerea & ns & $\mathrm{T}_{\mathrm{O}-\mathrm{F}}^{+}$ \\
\hline A & $\mathrm{P}$ & 79 & 41 & Pyrus communis & ns & $\mathrm{T}_{\mathrm{J}-\mathrm{A}}^{* * *}$ \\
\hline $\mathrm{A}$ & $\mathrm{C}$ & 74 & 37 & Brassica oleracea & ns & $\mathrm{T}_{\mathrm{J}-\mathrm{A}}^{*}$ \\
\hline $\mathrm{N}$ & $\mathrm{P}$ & 76 & 41 & Acer monspesolanum & ns & $\mathrm{T}_{\mathrm{J}-\mathrm{J}}^{* * *}$ \\
\hline $\mathrm{N}$ & $\mathrm{P}$ & 79 & 28 & Populus alba & ns & $\mathrm{T}_{\mathrm{J}-\mathrm{A}}^{* * *}$ \\
\hline $\mathrm{N}$ & $\mathrm{P}$ & 107 & 40 & Sorbus domestica & ns & $\mathrm{T}_{\mathrm{J}-\mathrm{A}}^{* *}$ \\
\hline $\mathrm{A}$ & $\mathrm{P}$ & 106 & 31 & Morus alba & ns & $\mathrm{T}_{\mathrm{J}-\mathrm{A}}^{* *}$ \\
\hline $\mathrm{E}$ & $\mathrm{P}$ & 102 & 35 & Platanus hybrida & ns & $\mathrm{T}_{\mathrm{J}-\mathrm{J}}^{* * *}$ \\
\hline $\mathrm{N}$ & $\mathrm{P}$ & 105 & 23 & Prunus spinosa & ns & $\mathrm{T}_{\mathrm{O}-\mathrm{F}}^{+}$ \\
\hline A & $\mathrm{P}$ & 112 & 40 & Juglans regia & ns & $\mathrm{T}_{\mathrm{J}-\mathrm{J}}^{*}$ \\
\hline $\mathrm{N}$ & $\mathrm{P}$ & 99 & 22 & Celtis australis & ns & $\mathrm{T}_{\mathrm{J}-\mathrm{A}}^{* *}$ \\
\hline $\mathrm{N}$ & $\mathrm{P}$ & 121 & 41 & Sambucus nigra & ns & $\mathrm{T}_{\mathrm{J}-\mathrm{A}}^{* *}$ \\
\hline $\mathrm{N}$ & $\mathrm{P}$ & 120 & 26 & Quercus faginea & ns & $\mathrm{P}_{\mathrm{S}-\mathrm{N}}^{+}$ \\
\hline $\mathrm{A}$ & $\mathrm{T}$ & 129 & 41 & Avena sativa & ns & $\mathrm{T}_{\mathrm{J}-\mathrm{J}}^{*}$ \\
\hline $\mathrm{N}$ & $\mathrm{P}$ & 139 & 39 & Quercus suber & ns & $\mathrm{T}_{\mathrm{J}-\mathrm{A}}{ }^{*}$ \\
\hline A & $\mathrm{T}$ & 132 & 36 & Hordeum vulgare & ns & $\mathrm{P}_{\mathrm{J}-\mathrm{J}}^{* *}$ \\
\hline A & $\mathrm{T}$ & 145 & 34 & Solanum tuberosum & ns & $\mathrm{T}_{\mathrm{J}-\mathrm{J}}^{+}$ \\
\hline $\mathrm{A}$ & $\mathrm{P}$ & 161 & 42 & Punica granatum & ns & $\mathrm{T}_{\mathrm{J}-\mathrm{J}}{ }^{* *}$ \\
\hline $\mathrm{N}$ & $\mathrm{C}$ & 182 & 33 & Satureja fruticosa & ns & $\mathrm{T}_{\mathrm{J}-\mathrm{J}}^{*}$ \\
\hline $\mathrm{N}$ & $\mathrm{P}$ & 318 & 39 & Arbutus unedo & ns & $\mathrm{T}_{\mathrm{O}-\mathrm{F}}^{* * *}$ \\
\hline $\mathrm{N}$ & $\mathrm{C}$ & 325 & 28 & Genista scorpius & ns & $\mathrm{P}_{\mathrm{J}-\mathrm{J}}^{* *}$ \\
\hline A & $\mathrm{T}$ & 192 & 24 & Zea mays & ns & ns \\
\hline
\end{tabular}


536 J. PEÑUELAS et al.

\begin{tabular}{lllllll}
\hline Origin & $\begin{array}{l}\text { Life- } \\
\text { forms }\end{array}$ & $\begin{array}{l}\text { Aproximate } \\
\text { date of } \\
\text { flowering }\end{array}$ & $\begin{array}{l}\text { Number of } \\
\text { observations }\end{array}$ & Species & $\begin{array}{l}\text { Advanced } \\
\text { days in } \\
\text { Flowering }\end{array}$ & $\begin{array}{l}\text { Most } \\
\text { correlated } \\
\text { climatic factor }\end{array}$ \\
\hline $\mathrm{A}$ & $\mathrm{T}$ & 133 & 41 & Triticum aestivum & $\mathrm{ns}$ & $\mathrm{ns}$ \\
$\mathrm{A}$ & $\mathrm{T}$ & 134 & 21 & Secale cereale & $\mathrm{ns}$ & $\mathrm{ns}$ \\
$\mathrm{N}$ & $\mathrm{C}$ & 106 & 37 & Thymus vulgaris & $\mathrm{ns}$ & $\mathrm{ns}$ \\
$\mathrm{N}$ & $\mathrm{P}$ & 139 & 29 & Pinus pinea & $-11.1^{+}$ & $\mathrm{T}_{\mathrm{J}-\mathrm{J}}^{*+}$ \\
$\mathrm{A}$ & $\mathrm{P}$ & 164 & 43 & Tilia cordata & $-25.3^{* * *}$ & $\mathrm{~T}_{\mathrm{O}-\mathrm{F}}^{*}$ \\
$\mathrm{~N}$ & $\mathrm{P}$ & 118 & 31 & Fraxinus angustifolia & $-37.2^{* * *}$ & $\mathrm{~ns}$ \\
\hline
\end{tabular}

$\mathrm{E}=$ Exotic; $\mathrm{A}=$ Agricultural; $\mathrm{N}=$ Native. Raunkiaer growth forms: $\mathrm{P}=$ Phanerophyte; $\mathrm{NP}=$ Nanophanerophyte; $\mathrm{T}=$ Terophyte; $\mathrm{C}=$ Chamaephyte; $\mathrm{H}=$ Hemicriptophyte. (taxonomy for all plant species are from Bolos et al. (1993); ns $=$ not significant; ${ }^{+} P<0.1$; ${ }^{*} \mathrm{P}<0.05 ;{ }^{* *} \mathrm{P}<0.01 ;{ }^{* * *} \mathrm{P}<0.001 ; \mathrm{T}=$ mean annual temperature; $\mathrm{P}$ annual precipitation; $\mathrm{T}_{\mathrm{J}-\mathrm{A}}=$ mean temperature from January to April; $\mathrm{T}_{\mathrm{J}-\mathrm{J}}=$ mean temperature from January to June; $\mathrm{T}_{\mathrm{O}-\mathrm{F}}=$ mean temperature from October to February; $\mathrm{P}_{\mathrm{S}-\mathrm{N}}=$ precipitation from September to November; $\mathrm{P}_{\mathrm{J}-\mathrm{J}}=$ precipitation from January to June).

Table 3 Number of advanced days in fruiting and the most correlated climate variable for each species. Period of observations: 1974-2000. Agricultural, exotic or native origin, Raunkiaer life-form, average Julian date of fruiting, number of observations, and significance of the regression analyses are also indicated for each species

\begin{tabular}{|c|c|c|c|c|c|c|}
\hline Origin & $\begin{array}{l}\text { Life- } \\
\text { form }\end{array}$ & $\begin{array}{l}\text { Aproximate } \\
\text { date of } \\
\text { fruiting }\end{array}$ & $\begin{array}{l}\text { Number of } \\
\text { observations }\end{array}$ & Species & $\begin{array}{l}\text { Advanced } \\
\text { days in } \\
\text { fruiting }\end{array}$ & $\begin{array}{l}\text { Most } \\
\text { correlated } \\
\text { climatic factors }\end{array}$ \\
\hline $\mathrm{N}$ & $\mathrm{P}$ & 316 & 20 & Quercus ilex & $42.6^{*}$ & $\mathrm{~T}_{\mathrm{J}-\mathrm{J}}^{* *}$ \\
\hline $\mathrm{A}$ & $\mathrm{P}$ & 235 & 22 & Corylus avellana & $31.1^{* * *}$ & $\mathrm{~T}^{* * *}$ \\
\hline $\mathrm{A}$ & $\mathrm{P}$ & 193 & 20 & Prunus cerasifera & $25.4^{* * *}$ & $\mathrm{~T}_{\mathrm{O}-\mathrm{J}}^{* *}$ \\
\hline $\mathrm{A}$ & $\mathrm{P}$ & 179 & 20 & Prunus armeniaca & $23.9^{*}$ & $\mathrm{~T}^{*-1}$ \\
\hline $\mathrm{A}$ & $\mathrm{P}$ & 287 & 22 & Cydonia oblonga & $23^{* * *}$ & $\mathrm{~T}_{\mathrm{O}-\mathrm{J}}^{* * *}$ \\
\hline $\mathrm{A}$ & $\mathrm{T}$ & 180 & 24 & Hordeum vulgare & $21.7^{* *}$ & $\mathrm{~T}^{* * *}$ \\
\hline $\mathrm{A}$ & $\mathrm{T}$ & 201 & 20 & Solanum lycopersicum & $19.1^{* *}$ & $\mathrm{~T}^{* * *}$ \\
\hline $\mathrm{A}$ & $\mathrm{T}$ & 181 & 24 & Triticum aestivum & $19.1^{* *}$ & $\mathrm{~T}^{* * *}$ \\
\hline $\mathrm{A}$ & $\mathrm{P}$ & 154 & 20 & Morus alba & $17.8^{*}$ & $\mathrm{~T}_{\mathrm{O}-\mathrm{J}}^{*}$ \\
\hline $\mathrm{A}$ & $\mathrm{P}$ & 250 & 20 & Prunus dulcis & 13.6 & $\mathrm{P}_{\mathrm{O}-\mathrm{F}}^{* *}$ \\
\hline $\mathrm{A}$ & $\mathrm{P}$ & 282 & 20 & Punica granatum & $12.1^{+}$ & $\mathrm{T}^{*}$ \\
\hline $\mathrm{A}$ & $\mathrm{P}$ & 271 & 21 & Vitis vinifera & $12^{*}$ & $\mathrm{~T}^{* *}$ \\
\hline $\mathrm{A}$ & $\mathrm{T}$ & 191 & 23 & Solanum tuberosum & $10.5^{+}$ & $\mathrm{T}^{* *}$ \\
\hline $\mathrm{A}$ & $\mathrm{P}$ & 297 & 22 & Castanea sativa & 4.5 & $\mathrm{~T}_{\mathrm{J}-\mathrm{J}}$ \\
\hline $\mathrm{A}$ & $\mathrm{P}$ & 163 & 20 & Prunus avium & ns & $\mathrm{P}_{\mathrm{J}-\mathrm{J}}^{+}$ \\
\hline $\mathrm{A}$ & $\mathrm{T}$ & 177 & 21 & Avena sativa & ns & $\mathrm{P}_{\mathrm{O}-\mathrm{J}}^{+}$ \\
\hline $\mathrm{A}$ & $\mathrm{P}$ & 210 & 20 & Pyrus communis & ns & $\mathrm{P}^{+}$ \\
\hline $\mathrm{A}$ & $\mathrm{P}$ & 283 & 21 & Malus domestica & ns & $\mathrm{P}^{+}$ \\
\hline $\mathrm{A}$ & $\mathrm{P}$ & 298 & 21 & Diospyros kaki & ns & $\mathrm{T}_{\mathrm{J}-\mathrm{J}}^{*}$ \\
\hline $\mathrm{A}$ & $\mathrm{T}$ & 170 & 21 & Vicia faba & ns & $\mathrm{P}_{\mathrm{J}-\mathrm{J}}^{+}$ \\
\hline $\mathrm{A}$ & $\mathrm{T}$ & 166 & 21 & Pisum sativum & ns & $\mathrm{P}_{\mathrm{J}-\mathrm{J}}^{+}$ \\
\hline $\mathrm{A}$ & $\mathrm{P}$ & 205 & 20 & Prunus domestica & ns & $\mathrm{T}_{\mathrm{S}-\mathrm{N}}{ }^{*}$ \\
\hline $\mathrm{A}$ & $\mathrm{T}$ & 207 & 22 & Cicer arietinum & ns & $\mathrm{P}_{\mathrm{O}-\mathrm{J}}^{* *}$ \\
\hline $\mathrm{A}$ & $\mathrm{P}$ & 262 & 22 & Ficus carica & ns & ns \\
\hline $\mathrm{A}$ & $\mathrm{P}$ & 266 & 21 & Juglans regia & ns & ns \\
\hline $\mathrm{A}$ & $\mathrm{P}$ & 238 & 21 & Prunus persica & $-27.3^{*}$ & $\mathrm{P}_{\mathrm{O}-\mathrm{J}}$ \\
\hline $\mathrm{N}$ & $\mathrm{P}$ & 291 & 20 & Arbutus unedo & $-19.2^{+}$ & $\mathrm{P}^{*-1}$ \\
\hline
\end{tabular}

$\mathrm{A}=$ Agricultural; $\mathrm{N}=$ Native. Raunkiaer growth Forms: $\mathrm{P}=$ Phanerophyte; $\mathrm{T}=$ Terophyte. (taxonomy for all plant species are from Bolos et al. (1993); $\mathrm{ns}=$ not significant; ${ }^{+} \mathrm{P}<0.1 ;{ }^{*} \mathrm{P}<0.05,{ }^{* *} \mathrm{P}<0.01,{ }^{* * *} \mathrm{P}<0.001 ; \mathrm{T}=$ mean annual temperature; $\mathrm{P}=$ annual precipitation; $\mathrm{T}_{\mathrm{S}-\mathrm{N}}=$ mean temperature from September to November; $\mathrm{T}_{\mathrm{J}-\mathrm{J}}=$ mean temperature from January to June; $\mathrm{T}_{\mathrm{O}-\mathrm{J}}=$ mean temperature from October to June; $\mathrm{P}_{\mathrm{J}-\mathrm{J}}=$ precipitation from January to June; $\mathrm{P}_{\mathrm{O}-\mathrm{F}}=$ precipitation from October to February). 
average has been 32.6 (SEM 2.23) days. The day of flowering has also advanced in 27 of the 57 species and has been delayed in 3, while 27 species showed no significant trend (Table 2, Fig. 2d). The advance has ranged between 7 and 70 days depending on the species, and their average advance has been 22.5 (SEM 2.75) days. When considering the whole set of species, the overall average advance is 9.5 days (SEM 7.5). The day of fruiting has also advanced since 1974 (when there is available data) in 14 of the 27 species, has been stable in 11 , and has been delayed in 2 (Table 3, Fig. 2e). The advance (since 1974) has ranged between 4 and 34 days depending on the species, and the average advance has been 19.1 (SEM 2.04) days. When considering the whole set of species, the overall average advance is 8.2 days (SEM 2.85).

Overall species linear trends Figure 3 shows the overall species linear annual trends of the different phenophases dates expressed as number of days of departure from the average phenophase date for each species (to standardize by species and thus to avoid discrepancies owing to species themselves). They show a global 16 days advance for leaf unfolding, 13 days delay for leaf fall, 6 days advance for flowering and 9 days advance for fruiting. In all the cases the stronger changes occurred in the last 25 years (Fig. 3). Thus, our linear treatment of the data is being conservative.

Differences in trends among species origins, growth forms and phenophase dates There were thus overwhelming general significant trends. Although there were great differences among species (Tables 1-3), ANOvA and correlation analyses showed these trends were not different among the different Raunkiaer growth forms (Fig. 4a), among different species origins (wild, agricultural or exotic species; Fig. 4b), or among a wide range of leaf unfolding, leaf fall, flowering and fruiting dates (from early to late season; Fig. 5), which reinforces confidence on general trends.

Comparison with the plant phenological trends of other regions The shifts in leaf phenology are stronger than those previously described for Europe by Menzel \& Fabian (1999) who reported an advanced spring of 6 days and a delayed autumn of 4.8 days over 30 years for an European area between Scandinavia and Macedonia. Moreover, they found the advancing trend mainly in their northern sites, while for the Balkan sites they reported a spring delay that was attributed to a particular regional pattern of climate change. The increase in growing season length reported here exceeds also the lengthening of about 7 days in the northern hemisphere that was inferred from atmospheric $\mathrm{CO}_{2}$ data taken between the 1960s and early 1990s, but coincides in most of the effect occurring after 1980
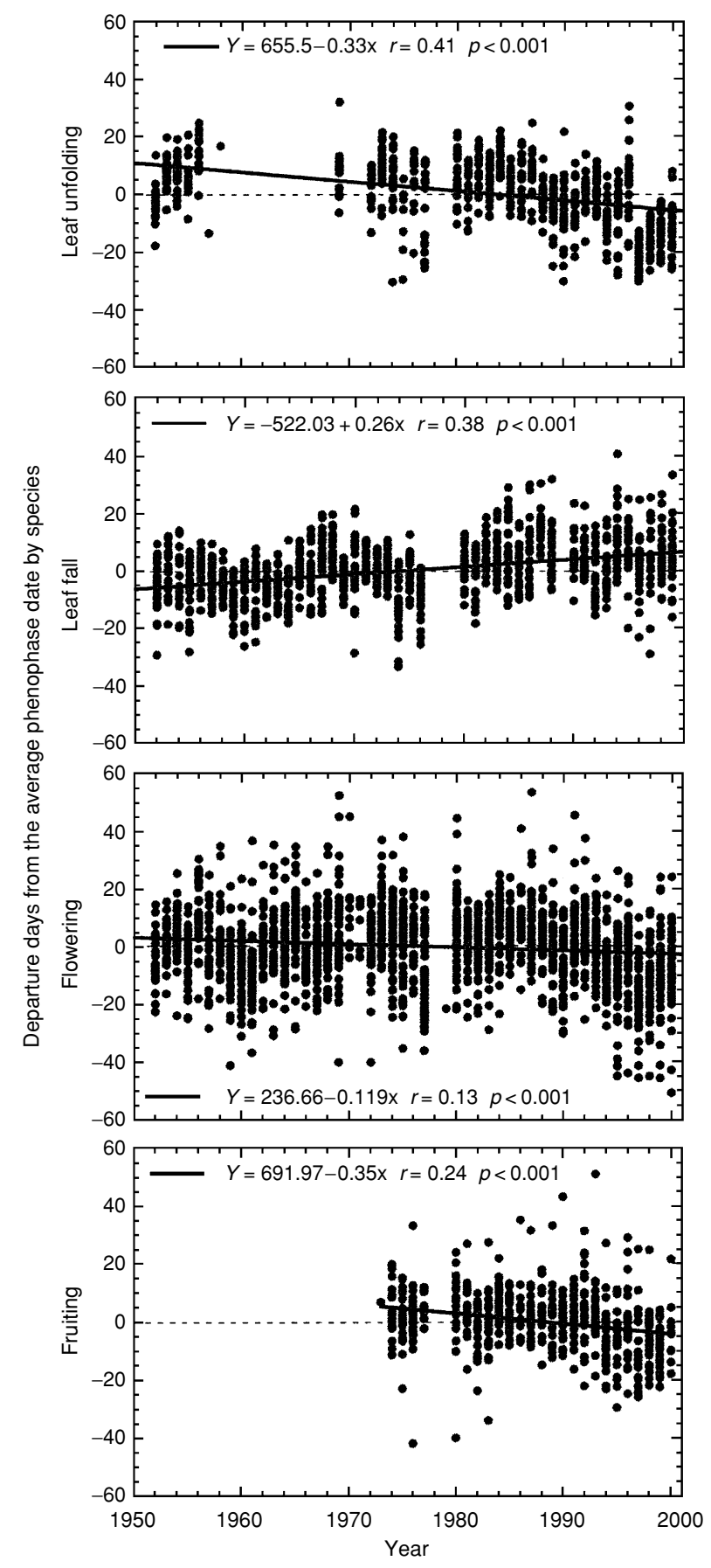

Fig. 3 Temporal trends of different phenophases (leaf unfolding, leaf fall, flowering and fruiting) for all the studied species (Tables 1-3). The phenology is expressed as departure from the average date by species. Lines represent linear regressions that were fitted to the data.

(Keeling et al., 1996). Our data are more in accordance with the apparent increase of $8 \pm 3$ days for the beginning of the growing season and the prolongation by $4 \pm 2$ days of the declining phase estimated by an analysis 
(a)

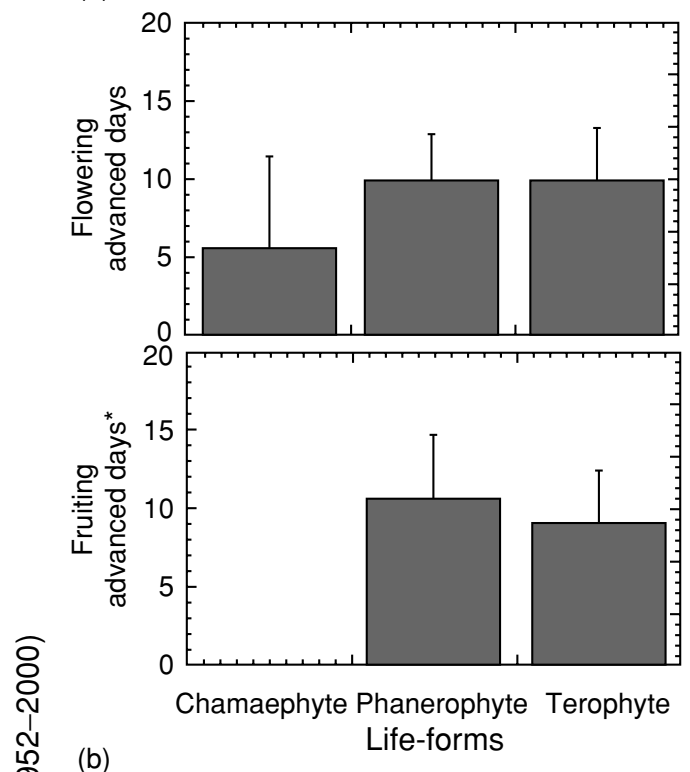

(b)

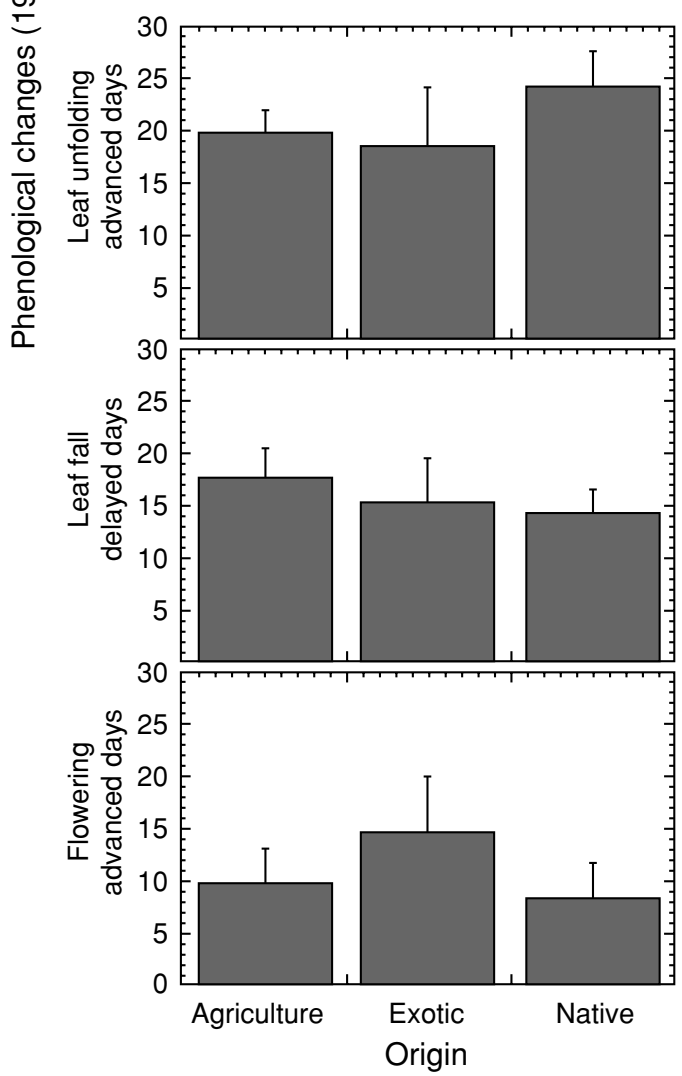

Fig. 4 Mean values of phenological changes in species of different life form (a), and in species of different origin (b). Bars are standard errors ( $n$ in Tables $1-3$ ). There were not significant differences among any life-form or origin (ANOvAs). ( ${ }^{*}$ For fruiting, the period of observations was 1974-2000).
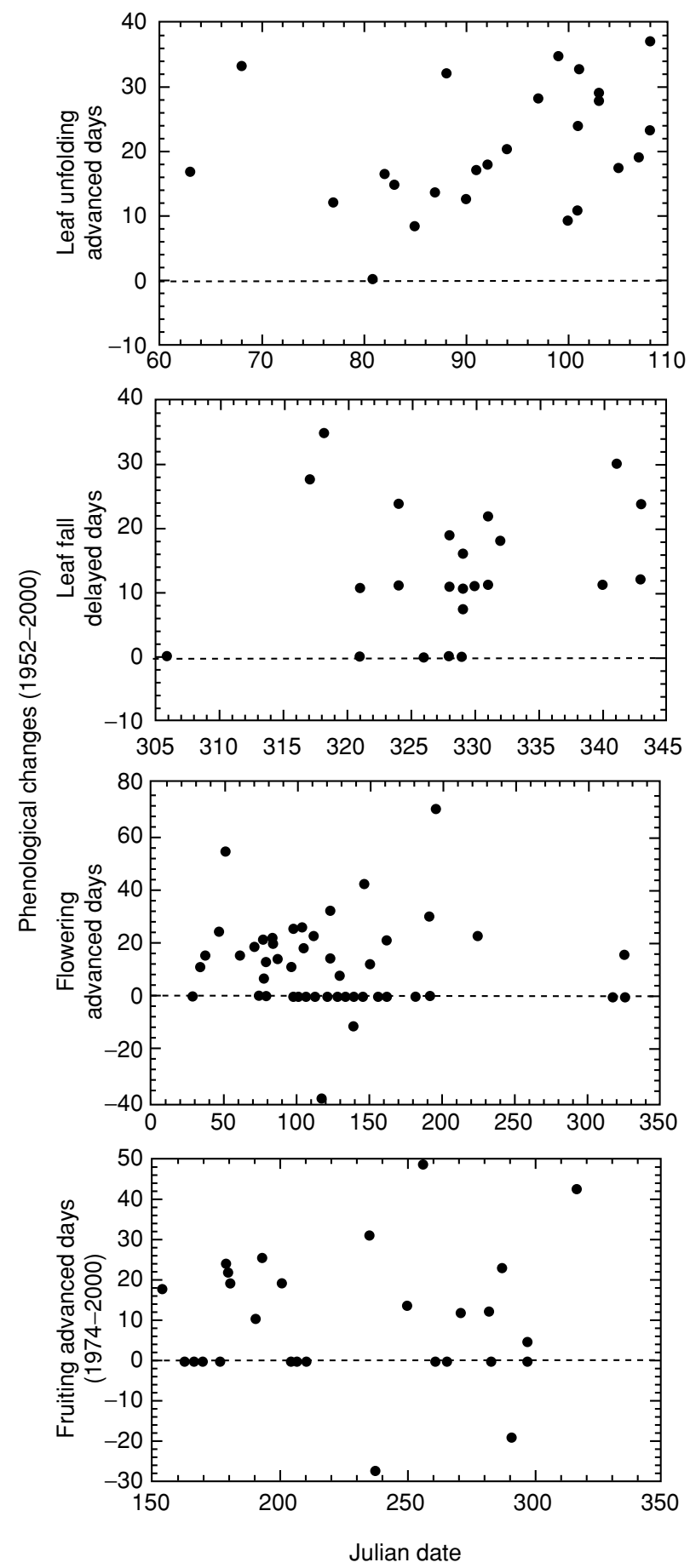

Fig. 5 Absence of significant relationship, for the studied species, between the number of advanced or delayed days during the studied period (1952-2000), and the average date for each phenophase. ( ${ }^{*}$ For fruiting the period of observations was 1974-2000). 
of NDVI satellite data of northern latitudes between $45^{\circ} \mathrm{N}$ and $70^{\circ} \mathrm{N}$ for the short period 1982-90 (Myneni et al., 1997).

Shifts in flowering dates found in our study are quite in agreement with the shifts observed in the previously reported data. For example, flowering of Robinia pseudoacacia in Hungary over the period 1851-1994 (Walkowszky, 1998) shifted by 3-8 days. However, for this same species, we found an advance in flowering date of 14.1 days (Table 2). The observed advancements are also stronger than those found by Bradley et al. (1999) for the period between 1936 and 1998 in Wisconsin, USA, where 10 species flowered 13 days in advance while 15 other species did not change. They are also stronger than the trends found by Abu-Asab et al. (2001) for the period between 1970 ad 1999 in the Washington, DC, area. There the average first flowering times for 100 species showed a significant advance of 2-4 days. Our data is in accordance with data showing that the timing of maximum pollen concentrations advanced by approximately 8.5 days per ${ }^{\circ} \mathrm{C}$ in a nearby Mediterranean area (Montpellier) (Osborne et al., 2000).

\section{Climate relationships}

During the period 1952-2000 mean annual temperature increased by $1.4{ }^{\circ} \mathrm{C}$ in our study area (Fig. 6a). It was calculated as the difference between the temperature at the study onset, in year 1952, and at the end of the study, in year 2000, derived from linear regression with time. The stronger change took place after the mid-1970s (Fig. 6a) in accordance with Catalonian (Piñol et al., 1998), Mediterranean (Jones et al., 1999) and global trends (IPCC, 2001). The months with greater average temperature increase (more than $2{ }^{\circ} \mathrm{C}$ ) were February and August (Fig. 6b). There were no significant changes in precipitation (Fig. 6a).

All the phenological changes were correlated with temperature changes (Fig. 7), especially with those of the temperatures of the months previous to the phenophase (Tables 1-3). The months preceding the phenological events seem the most determinant in most species, but not always. For some species, the mean annual temperature was the most correlated climate variable to the phenological changes, especially for fruiting (Tables 1-3). However, in most of those cases the differences of significance between annual temperature and temperatures of months preceding the phenological events were very slight. For a few species and phenophases (those with level of significance $P<0.001$ in Tables $1-3)$ changes in temperature statistically account for even more than $50 \%$ of the temporal trends.

For some species and phenophases there was also a weak but still significant correlation with the precipitation of the previous months. In some species which presented no significant changes within the studied period, the correlation of leaf fall, flowering or fruiting with precipitation was even stronger than with temperature (Tables 1-3). The changes towards more arid conditions owing to the increased temperature and air saturation deficits (increased evaporative demand) together with the absence of significant temporal trend with time in the precipitation record may reinforce this precipitation relationship in the near future. Interestingly, the species where precipitation had more significant impact are less drought tolerant (e.g. Aesculus hippocastanum, for leaf phenology, Quercus faginea or Genista scorpius for flowering) or are agricultural plants without irrigation (e.g. Hordeum vulgare, for flowering, Zea mays, Prunus dulcis, or Avena sativa for fruiting). Those species which showed little change in flowering or fruiting may be also more strictly controlled by photoperiod than by temperature (Romberger, 1963). Possible effects of increased atmospheric $\mathrm{CO}_{2}$ concentrations on phenological traits, such as flowering and fruiting (Peñuelas et al., 1995), cannot be discarded. For the agricultural plants, irrigation and fertilization practices have changed little in the area but they might also have affected the changes in some cases.

The correlational nature of this study limits our ability to determine causal factors. However, the available data and the current knowledge of plant phenology, including numerous experimental studies (Romberger, 1963; Larcher, 1995; Price \& Waser, 1998; Bradley et al., 1999), imply that the observed changes mostly responded to the increased temperatures. The critical temperature sum for leaf unfolding, flowering or fruiting has thus been attained earlier and the warmer autumn conditions have allowed the autumn delay. Moreover, the number of freezing days has significantly decreased from about 50-60 in the 1950s to about 20-30 in the 1990s (Fig. 6). Therefore, the probability of frost damage of young leaves and flowers has also decreased. However, those species requiring certain number of chilling days for budbursting (e.g. Prunus persica, Olea europea; Larcher, 1995) may suffer an impact not so linearly correlated with the temperatures.

\section{Animal responses}

Regarding animal phenology, the appearance of the butterfly Pieris rapae was also advanced by 11.4 days $(P<0.1)$ (Fig. 8a) and the most correlated climate variable was the temperature of the period between January and March $(P<0.01)$ (Fig. 8b). This is in agreement with the insects being expected to pass through their larval stages faster and to become adults earlier in response to climate warming, as reported in some previous studies. In effect, five species of aphids in the UK have shown an advance 

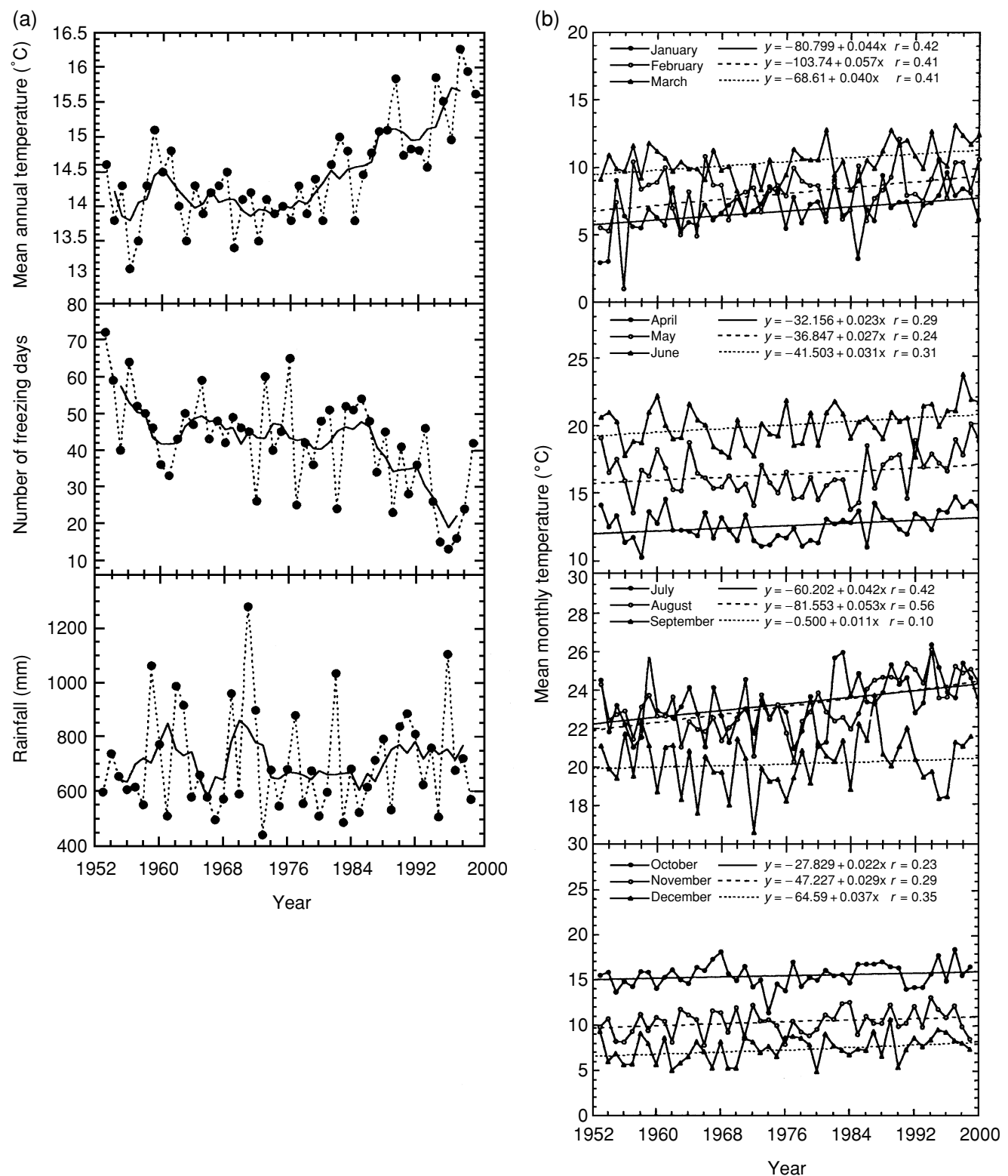

Fig. 6 Climate trends in the studied area (measured in the Cardedeu field station) during the period of study (1952-2000). (a) Mean annual temperature, and annual temperatures smoothed with five-year running mean, annual number of freezing days and their smooth with five-year running mean, and annual rainfall ( $\mathrm{mm}$ ) and their smooth with five-year running mean. (b) Mean monthly temperatures for the 12 months of the year, with lines representing linear regressions that were fitted to the data.

in flight phenology of 3-6 days over the past 25 years (Fleming \& Tatchell, 1995) possibly responding to an increase of $0.4{ }^{\circ} \mathrm{C}$. Peak flight for 104 species of the most common Microlepidoptera in The Netherlands (1955-94) showed a trend towards earlier flight that was strongest in 1975-94, when the date shifted forward by an average of 11.6 days (Ellis et al., 1997).

The advanced leafing, flowering, fruiting and appearance of insects are likely to have pronounced effects on the availability of food supplies for birds. However, contrary to the observed trends towards accelerated phenologies in plants and butterfly appearance, migratory bird arrival in spring (first sighting or listening) was curiously delayed in 5 of the 6 studied species and there were only very weak correlations with temperature or precipitation (Table 4, Fig. 9B). Figure 9a shows an example of this trend for one of the monitored species, Luscinia megarhynchos. Its arrival has been delayed by 14 days. The species overall average delay was 15.4 (SEM 10.2) days when calculated as the average species 

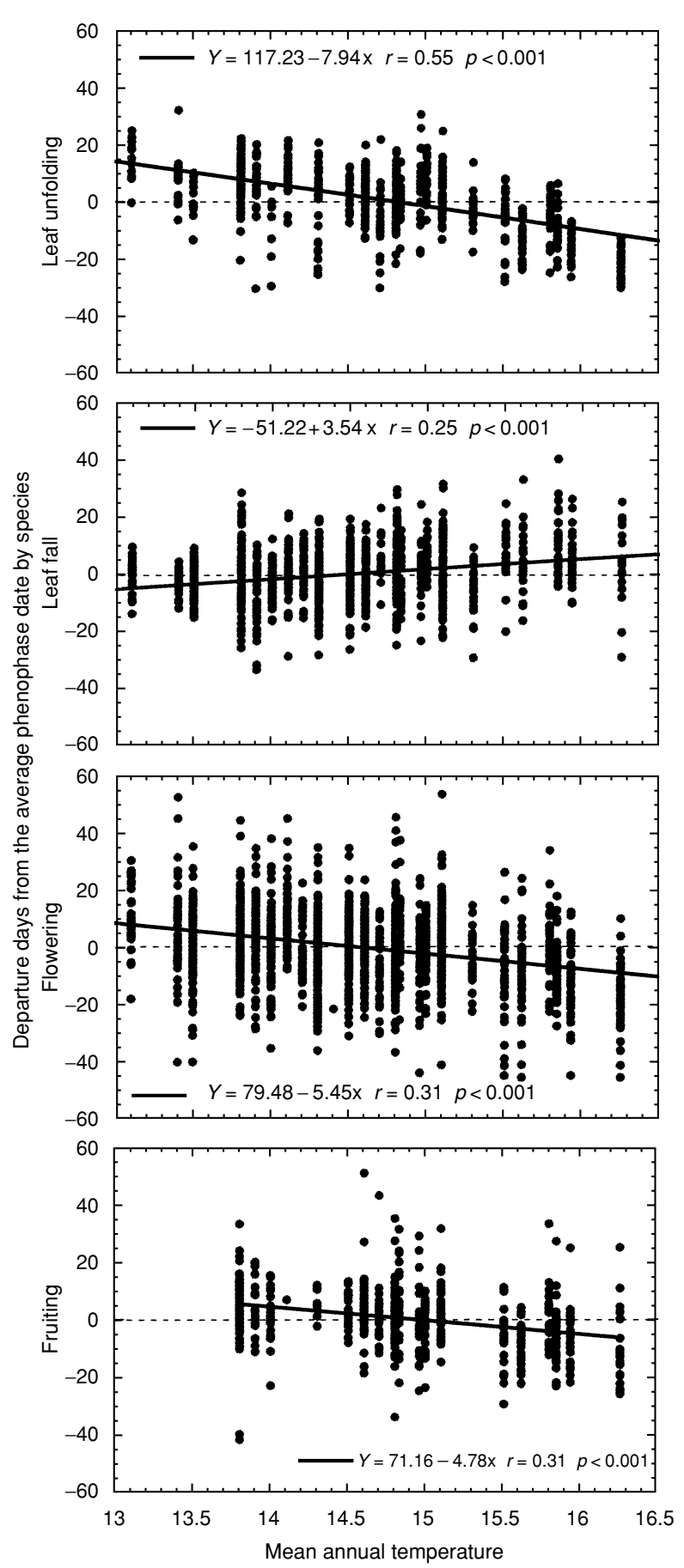

Fig. 7 Relationship between the changes during 1952-2000 in the phenophase dates expressed as departure from the average date by species and the mean annual temperature. Lines represent linear regressions that were fitted to the data.

differences between the arrival at 1952 and at 2000 from linear regressions with time (e.g. Fig. 9a). The species overall delay was 14 days when calculated in the overall species linear annual trends of arrival date expressed as (a)

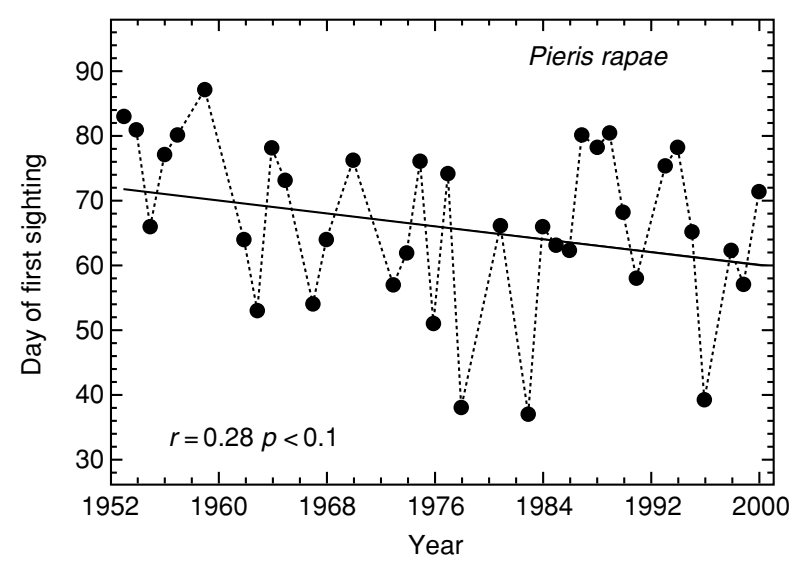

(b)

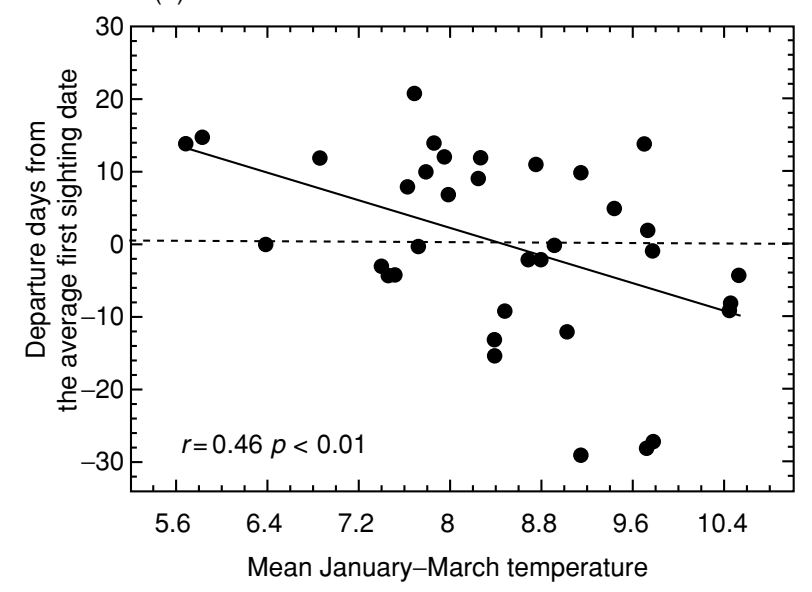

Fig. 8 (a) Changes during 1952-2000 in the Julian date of first appearance of the butterfly Pieris rapae in Cardedeu field station (NE Spain). (b) Relationship between the changes during 1952-2000 in the first sighting expressed as departure from the average date and the mean temperature between January and March. Lines represent linear regressions that were fitted to the data.

number of days of departure from the average arrival date for each species (Fig. 9c). These results are in apparent disagreement with some reports showing possible earlier arrival dates of spring migrants in the US and UK (Ball, 1983; Sparks, 1999). This different trend in migratory bird arrival could be owing to the factors other than temperature in the breeding region, like changed climatic conditions in African overwintering sites or along the migration route of the birds monitored in this study. The decreased food availability because of Sahelian droughts and deforestation is likely to favour birds arriving later to the southern European breeding grounds (Bell, 1996). Our results are in agreement with those of Mason (1995) who found a trend towards later 
(a)

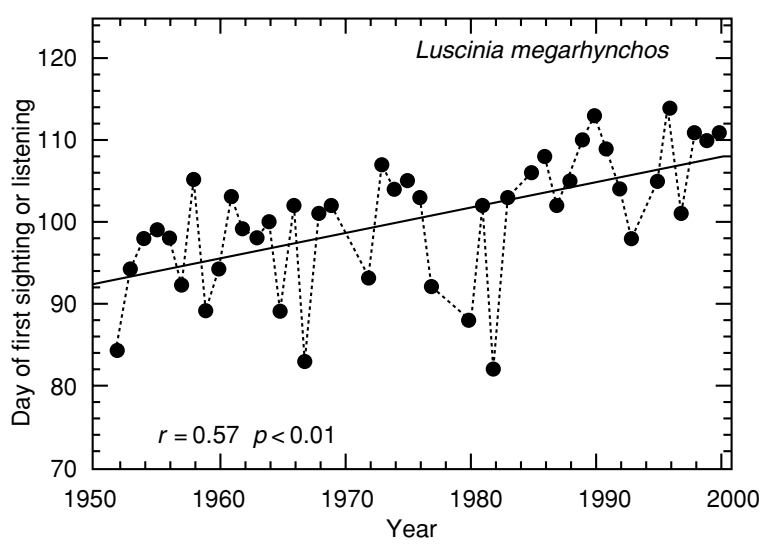

(b)

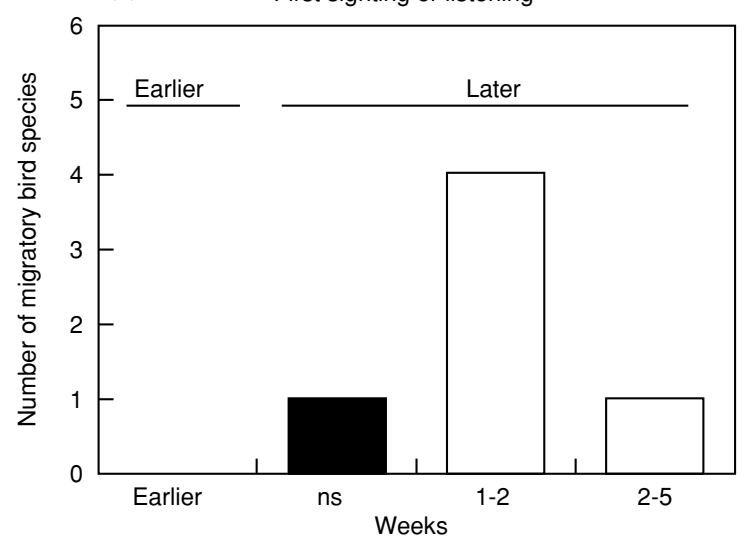

(c)

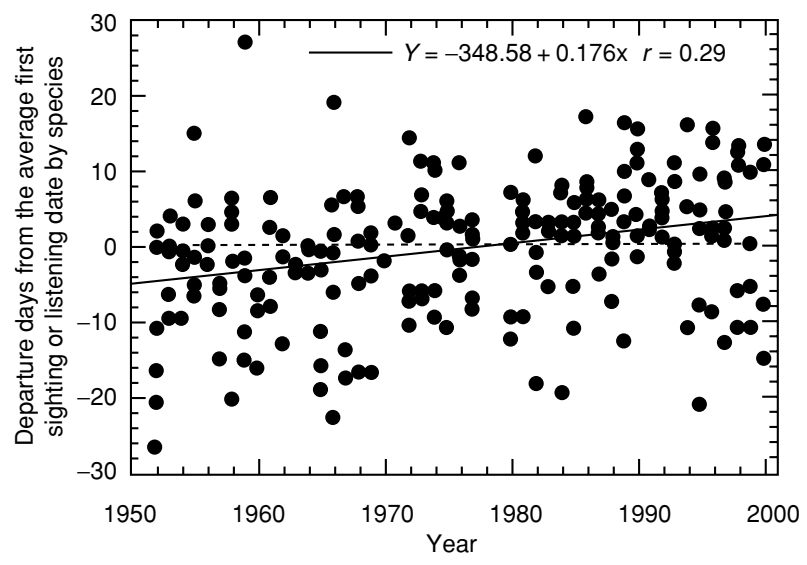

Fig. 9 (a) Temporal trend of the day of first appearance of the migratory bird Luscinia megarhynchos as an example of migratory bird. (b) Frequency distribution of the bird species with delaying trends in first sighting or listening. Significant trends $(P<0.05)$ are shown in white, nonsignificant in grey. (c) Temporal trend of the date of first appearance for all the studied migratory bird species (Table 4) expressed as departure from the average date by species. Lines represent linear regressions that were fitted to the data. arrival for migratory birds wintering south of the Sahel. This is the area where all the birds studied here spend the winter months with the exception of Upupa epops that may keep a small part of the population overwintering in southern European grounds, in an additional indication of climate warming. Moreover, when these subsaharian migratory birds set out from their origin site, they do not know the weather at their destination. In any case, these findings support previous results demonstrating that migratory birds can be affected by shifts in global climate patterns (Sillet et al., 2000).

\section{Altered ecological processes}

The observed changes in plant phenology and bird migration clearly demonstrate the potential for a decoupling of species interactions such as between plants and their pollinators or between bird physiology and their food supply. Birds may be adversely affected if they become unsynchronized with the phenology of their food supplies (Crick et al., 1997). This effect has been suggested by Visser et al. (1998); who reported for the UK a decoupling owing to earlier plant development between the food supply and the timing of breeding of the Great Tit, which remained unchanged. In our study there were great differences of phenological responses among species. A few plant species even showed a delay in flowering or fruiting. This was also seen by Fitter et al. (1995), and is likely to result in highly unpredictable community-level impacts. The different responses of the studied species to climatic warming may alter their competitive ability and thus their ecology and conservation, with likely future changes in structure and functioning of ecosystems.

Another important alteration of ecological processes derived from these phenological changes is the possibility of lengthening of the growing season through the extended leaf life in deciduous species. The lengthening of the growing season in the northern hemisphere (Peñuelas \& Filella, 2001), including these Mediterranean latitudes, is likely to contribute to the global increase in biospheric activity inferred from the $20 \%$ increase in the amplitude of the atmospheric $\mathrm{CO}_{2}$ annual oscillation in Hawaii during the period 1960-94 (Keeling et al., 1996) and from satellite remote sensing during the 1980s (Ellis et al., 1997; Myneni et al., 1997). The accelerated tree growth across Europe previously attributed to fertilization by nitrogen compounds and increased $\mathrm{CO}^{2}$ (Spiecker et al., 1996) may also have another driver in this extended growing period. However, as plant growth in Mediterranean ecosystems is usually water limited, the interaction between longer growth season and climatic changes in water availability needs to be studied at this regard. 
Table 4 Number of delayed days in first sighting or listening for bird species accompanied by the most correlated climate variable. Period of observations: 1952-2000

\begin{tabular}{|c|c|c|c|}
\hline $\begin{array}{l}\text { Aproximate date } \\
\text { of first sighting or } \\
\text { listening }\end{array}$ & $\begin{array}{l}\text { Subsaharian } \\
\text { migratory bird } \\
\text { species }\end{array}$ & $\begin{array}{l}\text { Delayed days in } \\
\text { first sighting } \\
\text { or listening }\end{array}$ & $\begin{array}{l}\text { Most } \\
\text { correlated } \\
\text { climatic factors }\end{array}$ \\
\hline 55 & Upupa epops $^{(1)}$ & 11.6 & ns \\
\hline 76 & Hirundo rustica, & 7.2 & $\mathrm{~T}_{\mathrm{O}-\mathrm{J}}^{*}$ \\
\hline 103 & Cuculus canorus & 11.4 & $\mathrm{~T}^{*}$ \\
\hline 100 & Luscinia megarhynchos & 13.7 & $\mathrm{~T}^{*}$ \\
\hline 114 & Coturnix coturnix & 33.3 & $\mathrm{~T}_{\mathrm{O}-\mathrm{J}}^{*}$ \\
\hline 112 & Apus apus & ns & $-\mathrm{P}_{\mathrm{S}-\mathrm{N}}^{*}$ \\
\hline
\end{tabular}

${ }^{(1)} \mathrm{A}$ small part of the population may remain overwintering in southern Europe grounds.(ns = not significant; ${ }^{*} \mathrm{P}<0.05 ; \mathrm{T}=$ mean annual temperature; $\mathrm{P}=$ annual precipitation; $\mathrm{T}_{\mathrm{O}-\mathrm{J}}=$ mean temperature from October to June; $\mathrm{P}_{\mathrm{S}-\mathrm{N}}=$ precipitation from September to November).

\section{Conclusions}

There is a now increasing evidence that climate change affects biological and ecological processes. Our data add evidence pointing towards climate-driven biospheric changes also in more southern and warmer and drier latitudes than those mostly monitored in previous studies. The phenophase dates and therefore the life cycle of many common Mediterranean plants, migratory birds and butterfly species are being profoundly altered. Climate warming seems to be a main driver of such alteration but other factors of global change (nutrient enrichment, $\mathrm{CO}_{2}$ fertilization, irrigation practices for agricultural species) may also affect them. The decoupling of species interactions because of the different responses of the species may also alter the structure and functioning of communities. The lengthening of plant growing season is likely to increase the Mediterranean ecosystems activity. Finally, it should be kept in mind that the observed changes have occurred with warming levels of only one half or even less of those expected over the next century (IPCC, 2001). Therefore, our data constitute another indication that future climate warming could become a major force in changing life the way we know it in our ecosystems.

\section{Acknowledgements}

We thank the financial support of DURSI-DMA IMMPACTE 1999 (Catalonia), CICYT REN 2000-028/CLI (Spain) and Fundació Territori i Paisatge, the insightful comments of J. Terradas, F. Rodà, F. Lloret and R. Aymí, and the logistic help of M. Boada.

\section{References}

Abu-Asab M, Peterson PM, Shetler SG, Orly S (2001) Earlier plant flowering in spring as a response to global warming in the Washington, DC, area. Biodiversity and Conservation, 10, 597-612.

Ball T (1983) The migration of geese as an indicator of climate change in the southern Hudson Bay region between 1715 and 1851. Climatic Change, 5, 85-93.

Bell CP (1996) Seasonality and time allocation as causes of leapfrog migration in the Yellow Wagtail Motacilla flava. Journal of Avian Biology, 27, 334-342.

Bolos O, Vigo J, Masalles RM, Ninot JM (1993) Flora Manual dels Països Catalans. Editorial Pòrtic s.a., Barcelona, 1240 pp.

Bradley NL, Leopold AC, Ross J, Huffaker W (1999) Phenological changes reflect climate change in Wisconsin. Proceedings of the National Academy of Sciences USA, 96 (17), 9701-9704.

Burroughs WJ (1992) Weather Cycles. Cambridge University Press, Cambridge, 201 pp.

Crick HQ, Dudley C, Glue DE (1997) UK birds are laying eggs earlier. Nature, 388, 526.

Ellis WN, Donner JH, Kuchlein JH (1997) Recent shifts in phenology of Microlepidoptera, related to climatic change (Lepidoptera). Entomologische Berichten, Amsterdam, 57, 66-72.

Fitter AH, Fitter RSR, Harris ITB, Williamson MH (1995) Relationship between first flowering date and temperature in the flora of a locality in central England. Functional Ecology, 9, 55-60.

Fleming RA, Tatchell GM (1995) Insects in a Changing Environment (eds Harrington R, Stork N). Academic Press, New York, pp. 505-508.

Hughes L (2000) Biological consequences of global warming: is the signal already apparent? Trends in Ecology and Evolution, 15, 56-56.

IPCC (2001) Climate Change 2001: The Scientific Basis. Contribution of Working Group I in The Third Assessment Report of the Intergovernmental Panel on Climate Change (eds Houghton JT, Ding Y, Griggs DJ, Noguer M, van der Linden PJ, Dai X, Maskell K, Johnson CA), Cambridge University Press, Cambridge, 881 pp.

Jones PD, New M, Parker DE, Martin S, Rigor IG (1999) Surface air temperature and its changes over the past 150 years. Reviews of Geophysics, 37, 173-199. 
Keeling CD, Chin JFS, Whorf TP (1996) Increased activity of northern vegetation inferred from atmospheric $\mathrm{CO}_{2}$ measurements. Nature, 382, 146-149.

Larcher W (1995) Physiological Plant Ecology. Springer, Berlin, $506 \mathrm{pp}$.

Mason CF (1995) Long term trends in the arrival dates of spring migrants. Bird Study, 42, 182-189.

Menzel A, Fabian P (1999) Growing season extended in Europe. Nature, 397, 659.

Myneni RB, Keeling CD, Tucker CJ, Asrar G, Nemani RR (1997) Increased plant growth in the northern high latitudes from 1981 to 1991. Nature, 386, 698-702.

Osborne CP, Chuine I, Viner D, Woodward FI (2000) Olive phenology as a sensitive indicator of future climatic warming in the Mediterranean. Plant, Cell and Environment, 23, 701-710.

Peñuelas J, Biel C, Estiarte M (1995) Growth, biomass allocation, and phenology of pepper plants submitted to elevated $\mathrm{CO}_{2}$ and different nitrogen and water availabilities. Photosynthetica, 31, 91-99.

Peñuelas J, Filella I (2001) Phenology: Responses to a warming world. Science, 294, 793-794.

Piñol J, Terradas J, Lloret F (1998) Climate warming, wildfire hazard, and wildfire occurrence in coastal eastern Spain. Climatic Change, 38, 345-357.
Price MV, Waser NM (1998) Effects of experimental warming on plant reproductive phenology in a subalpine meadow. Ecology, 79, 1261-1271.

Romberger JA (1963) Meristems growth and development in woody plants. USDA Technical Bulletin, No. 1292. U.S. Government Printing Office, Washington, DC, 214.

Scharwtz MD (1998) Green-wave phenology. Nature, 394, 839-840.

Sillet TS, Holmes RT, Sherry TW (2000) Impacts of a Global Climate Cycle on Population Dynamics of a Migratory Songbird. Science, 288, 2040-2041.

Sparks TH (1999) Phenology and the changing pattern of bird migration in Britain. International Journal of Biometeorology, 42, 134-138.

Spiecker H, Mielikäinen K, Köhl M, Skovsgaard JP, (eds) (1996) Growth Trends in European Forests: Studies from 12 Countries. Springer, Berlin, 372 pp.

Visser ME, Vannoordwijk AJ, Tinbergen JM, Lessells CM (1998) Warmer springs lead to mistimed reproduction in Great Tits (Parus major). Proceedings of the Royal Society of London-Series B: Biological Sciences, 265, 1867-1870.

Walkowszky A (1998) Changes in phenology of the locus tree (Robinia pseudoacacia L.) in Hungary. International Journal of Biometeorology, 41, 155-160. 